\title{
Crystal Structure of a Novel Proton Transfer Compound: Propane-1,3- diaminium Pyridine-3,5-dicarboxylate Monohydrate
}

\author{
Hossein Aghabozorg, ${ }^{\dagger}$ Mohammad Ghadermazi, and Andya Nemati \\ Department of Chemistry, Teacher Training University, Tehran, Iran
}

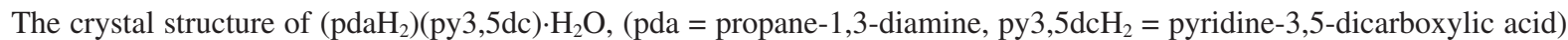
was determined by an X-ray diffraction method. This compound crystallized in the monoclinic system; space group $P 2_{1} / c$, with four formula units in the unit cell. The unit-cell parameters are $a=8.7213(9) \AA, b=19.5049(19) \AA, c=$ $8.0942(8) \AA$ with $\beta=112.842(5)^{\circ}$. The final $R$ value is 0.0430 for 2259 measured reflections. The most important features in the crystal structure of this compound are the presence of ion-pairing and a large number of $\mathrm{O}-\mathrm{H} \cdots \mathrm{O}, \mathrm{N}-\mathrm{H} \cdots \mathrm{O}$ and $\mathrm{N}-\mathrm{H} \cdots \mathrm{N}$ hydrogen bonds.
\end{abstract}

(Received June 12, 2006; Accepted August 4, 2006; Published on web September 20, 2006)

Our research group has been concerned with the synthesis of water-soluble proton-transfer self-associated systems that can function as suitable ligands in the synthesis of metal-organo compounds. ${ }^{1,2}$ The approach that we have applied is based on the proton-transfer processes between appropriate carboxylic acids and amines and the fact that ion-pairing and intermolecular forces, such as $\mathrm{H}$-bonding and $\pi$ - $\pi$ stacking can provide a large part of the stabilization energy of the resulting self-associated systems. In connection with such systems, we have already reported cases in which proton transfer from pyridine-2,6-dicarboxylic acid, pydcH $\mathrm{H}_{2}$ and 1,10phenanthroline-2,9-dicarboxylic acid, phendc $\mathrm{H}_{2}$, to 2,6pyridinediamine, pyda, and guanidine, $G$, resulted in the formation of novel proton-transfer (pydaH) $(\mathrm{pydcH}),{ }^{1}$ $\left(\right.$ pydaH $\left._{2}\right)($ phendc $),{ }^{2}$ and $(\mathrm{GH})_{2}($ pydc $),{ }^{3}$ systems. In continuation of our research project, ${ }^{4}$ the synthesis of a self associated system $\left(\right.$ pdaH $\left._{2}\right)($ py3,5dc $) \cdot \mathrm{H}_{2} \mathrm{O} \quad($ pda $=$ propane-1,3-diamine, py $3,5 \mathrm{dcH}_{2}=$ pyridine-3,5-dicarboxylic acid) is reported. This system arises from ion-pairing, hydrogen bonding interactions. The proton-transfer compound $\left(\mathrm{pdaH}_{2}\right)(\mathrm{py} 3,5 \mathrm{dc}) \cdot \mathrm{H}_{2} \mathrm{O}$ was prepared by a reaction between pyridine-3,5-dicarboxylic acid, pydcH $\mathrm{H}_{2}$, and propane-1,3-diamine, pda, in 1:1 molar ratio. To a solution of pda $(2 \mathrm{mmol}, 148 \mathrm{mg})$ in THF $(20 \mathrm{~mL})$ was added a solution of py $3,5 \mathrm{dcH}_{2}(334 \mathrm{mg}, 2 \mathrm{mmol})$ in THF $(100 \mathrm{~mL})$. The result was a white precipitate, which was filtered off and dried. The resulting powder was dissolved in water to give colorless crystals of the compound after four weeks. X-ray data were collected by graphite-monochromated Mo $K_{\alpha}$ radiation

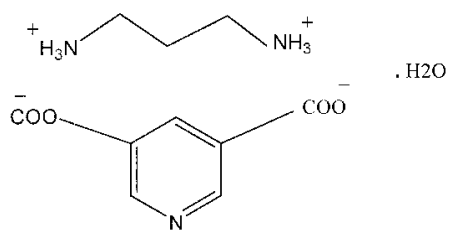

Fig. 1 Chemical structure of the title compound.

$\uparrow$ To whom correspondence should be addressed.

E-mail: aghabozorg@saba.tmu.ac.ir
( $\lambda=0.71073 \AA$ ). The crystal and experimental data are listed in Table 1. The structure was solved by direct methods using SHELXL-97. ${ }^{5}$ The structure was refined by a full-matrix leastsquare analysis on $F^{2}$ with SHELXL. The absorption was performed semi-empirically from equivalent by means of the SADABs program. The hydrogen atoms of water molecules and $\mathrm{H}(\mathrm{N})$ atoms were found in difference Fourier synthesis. The $\mathrm{H}(\mathrm{C})$ atom positions were calculated. All hydrogen atoms were refined in an isotropic approximation in a riding model

Table 1 Crystal and experimental data

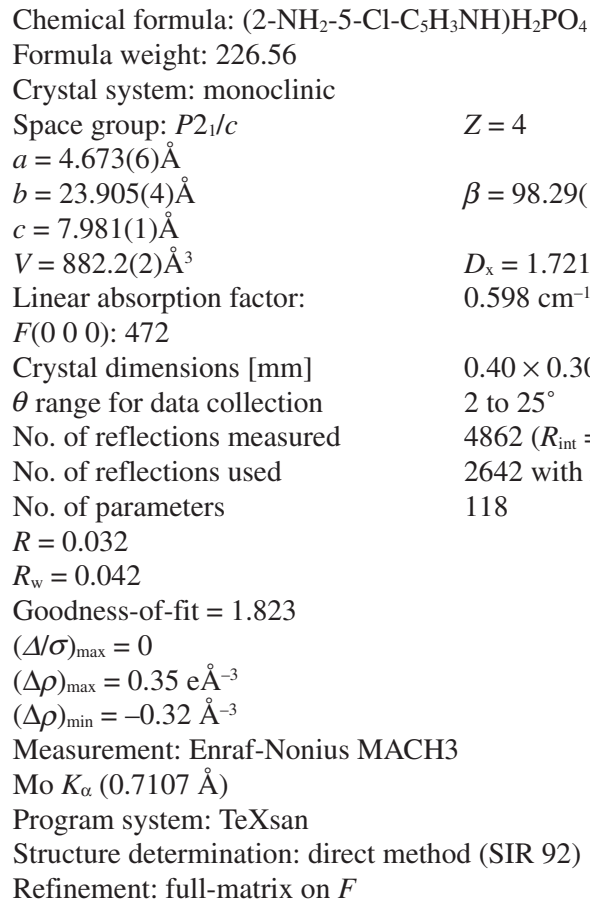

CCDC 608267 contains the supplementary crystallographic data for this paper. These data can be obtained free of charge from The Cambridge crystallographic Data Centre via www.ccdc.cam.ac.uk/data_request/cif. 
Table 2 Selected bond lengths $(\check{A})$, bond angles $\left(^{\circ}\right)$ and torsion angles $\left(^{\circ}\right)$ for $\left(\mathrm{pdaH}_{2}\right)(\mathrm{py} 3,5 \mathrm{dc}) \cdot \mathrm{H}_{2} \mathrm{O}$

\begin{tabular}{llll}
\hline $\mathrm{O}(1)-\mathrm{C}(6)$ & $1.263(2)$ & $\mathrm{N}(1)-\mathrm{C}(5)$ & $1.339(2)$ \\
$\mathrm{O}(2)-\mathrm{C}(6)$ & $1.251(2)$ & $\mathrm{C}(6)-\mathrm{C}(2)$ & $1.507(2)$ \\
$\mathrm{O}(3)-\mathrm{C}(7)$ & $1.254(2)$ & $\mathrm{C}(7)-\mathrm{C}(4)$ & $1.507(2)$ \\
$\mathrm{O}(4)-\mathrm{C}(7)$ & $1.265(2)$ & $\mathrm{N}(2)-\mathrm{C}(8)$ & $1.480(2)$ \\
$\mathrm{N}(1)-\mathrm{C}(1)$ & $1.342(2)$ & $\mathrm{N}(3)-\mathrm{C}(10)$ & $1.483(2)$ \\
\hline $\mathrm{O}(1)-\mathrm{C}(6)-\mathrm{C}(2)$ & $117.4(1)$ & $\mathrm{O}(3)-\mathrm{C}(7)-\mathrm{C}(4)$ & $117.0(1)$ \\
$\mathrm{O}(2)-\mathrm{C}(6)-\mathrm{C}(2)$ & $117.5(1)$ & $\mathrm{O}(4)-\mathrm{C}(7)-\mathrm{C}(4)$ & $117.9(1)$ \\
$\mathrm{O}(1)-\mathrm{C}(6)-\mathrm{O}(2)$ & $125.1(1)$ & $\mathrm{O}(3)-\mathrm{C}(7)-\mathrm{O}(4)$ & $125.0(1)$ \\
$\mathrm{C}(8)-\mathrm{C}(9)-\mathrm{C}(10)$ & $109.4(1)$ & $\mathrm{N}(2)-\mathrm{C}(8)-\mathrm{C}(9)$ & $111.8(1)$ \\
$\mathrm{C}(1)-\mathrm{N}(1)-\mathrm{C}(5)$ & $117.6(1)$ & $\mathrm{N}(3)-\mathrm{C}(10)-\mathrm{C}(9)$ & $111.6(1)$ \\
$\mathrm{C}(3)-\mathrm{C}(2)-\mathrm{C}(6)$ & $121.0(1)$ & $\mathrm{C}(3)-\mathrm{C}(4)-\mathrm{C}(7)$ & $121.2(1)$ \\
$\mathrm{C}(3)-\mathrm{C}(2)-\mathrm{C}(1)$ & $117.8(1)$ & $\mathrm{C}(5)-\mathrm{C}(4)-\mathrm{C}(7)$ & $120.9(1)$ \\
$\mathrm{C}(1)-\mathrm{C}(2)-\mathrm{C}(6)$ & $121.2(1)$ & $\mathrm{C}(5)-\mathrm{C}(4)-\mathrm{C}(3)$ & $117.9(1)$ \\
& & & \\
\hline $\mathrm{O}(1)-\mathrm{C}(6)-\mathrm{C}(2)-\mathrm{C}(1)$ & $3.9(2)$ & $\mathrm{O}(4)-\mathrm{C}(7)-\mathrm{C}(4)-\mathrm{C}(5)$ & $20.4(2)$ \\
$\mathrm{O}(2)-\mathrm{C}(6)-\mathrm{C}(2)-\mathrm{C}(1)$ & $-177.6(1)$ & $\mathrm{N}(2)-\mathrm{C}(8)-\mathrm{C}(9)-\mathrm{C}(10)$ & $-179.9(1)$ \\
$\mathrm{O}(3)-\mathrm{C}(7)-\mathrm{C}(4)-\mathrm{C}(5)$ & $-157.8(1)$ & $\mathrm{N}(3)-\mathrm{C}(10)-\mathrm{C}(9)-\mathrm{C}(8)$ & $174.3(1)$ \\
\hline
\end{tabular}

Table 3 Hydrogen bonds for $\left(\mathrm{pdaH}_{2}\right)(\mathrm{py} 3,5 \mathrm{dc}) \cdot \mathrm{H}_{2} \mathrm{O}\left[\AA{ }^{\circ},{ }^{\circ}\right]$

\begin{tabular}{lcccc}
\hline $\mathrm{D}-\mathrm{H} \ldots \mathrm{A}$ & $\mathrm{d}(\mathrm{D}-\mathrm{H})$ & $\mathrm{d}(\mathrm{H} \ldots \mathrm{A})$ & $\mathrm{d}(\mathrm{D} \ldots \mathrm{A})$ & $<(\mathrm{DHA})$ \\
\hline $\mathrm{O}(1 \mathrm{~S})-\mathrm{H}(1 \mathrm{~S}) \cdots \mathrm{O}(1) \# 1$ & 0.84 & 2.01 & $2.819(2)$ & 162 \\
$\mathrm{~N}(2)-\mathrm{H}(2 \mathrm{~A}) \cdots \mathrm{O}(4) \# 2$ & 0.91 & 1.93 & $2.775(2)$ & 154 \\
$\mathrm{~N}(2)-\mathrm{H}(2 \mathrm{~B}) \cdots \mathrm{O}(1)$ & 0.91 & 1.89 & $2.795(2)$ & 174 \\
$\mathrm{~N}(2)-\mathrm{H}(2 \mathrm{C}) \cdots \mathrm{O}(2) \# 3$ & 0.91 & 1.83 & $2.737(2)$ & 178 \\
$\mathrm{O}(1 \mathrm{~S})-\mathrm{H}(2 \mathrm{~S}) \cdots \mathrm{O}(4) \# 4$ & 0.88 & 1.90 & $2.766(2)$ & 169 \\
$\mathrm{~N}(3)-\mathrm{H}(3 \mathrm{~B}) \cdots \mathrm{O}(3) \# 5$ & 0.91 & 1.85 & $2.732(2)$ & 163 \\
$\mathrm{~N}(3)-\mathrm{H}(3 \mathrm{C}) \cdots \mathrm{O}(1 \mathrm{~S})$ & 0.91 & 1.89 & $2.786(2)$ & 170 \\
$\mathrm{~N}(3)-\mathrm{H}(3 \mathrm{D}) \cdots \mathrm{N}(1) \# 6$ & 0.91 & 2.00 & $2.854(2)$ & 157 \\
\hline
\end{tabular}

Symmetry transformations used to generate equivalent atoms:

$\# 1-x+1,-y+1,-z+3 ; \# 2 x+1,-y+3 / 2, z+1 / 2 ; \# 3-x+1,-y+1,-z+2$; \#4 $-x+1, y-1 / 2,-z+5 / 2 ; \# 5 x+1,-y+3 / 2, z+3 / 2 ; \# 6 x,-y+3 / 2, z+1 / 2$.

with $U_{\text {iso }}(\mathrm{H})=1.2 U_{\text {eq }}(\mathrm{Ci})$, for the $\mathrm{NH}_{3}$ group equal to $1.5 U_{\text {eq }}(\mathrm{Nii})$, where $U(\mathrm{Ci})$ and $U(\mathrm{Nii})$ are, respectively, the equivalent thermal parameters of the carbon and nitrogen atoms to which corresponding $\mathrm{H}$ atoms are bonded. The final $R$ value is 0.0430 . Some selected bond distances and angles and torsion angles are given in Table 2. The intermolecular hydrogen bond distances are listed in Table 3. The numbering scheme as well as ORTEP and crystal-packing diagrams are shown in Figs. 2 and 3, respectively. A remarkable feature in the crystal structure of the compound is the presence of a large number of $\mathrm{O}-\mathrm{H} \cdots \mathrm{O}, \mathrm{N}-\mathrm{H} \cdots \mathrm{O}$ and $\mathrm{N}-\mathrm{H} \cdots \mathrm{N}$ hydrogen bonds (Fig. 3 and Table 3). The shortest hydrogen bond is $\mathrm{N}(3)-\mathrm{H}(3 \mathrm{~B}) \cdots \mathrm{O}(3) \# 5$ (\#5: $x+$ $1,-y+3 / 2, z+3 / 2)$ with $\mathrm{D} \cdots \mathrm{A}=2.732(2) \AA ̊$ being a very strong interaction. The hydrogen bonds connect the different components, thus forming infinite layers that are finally linked together to form a hydrogen-bonded three-dimensional network

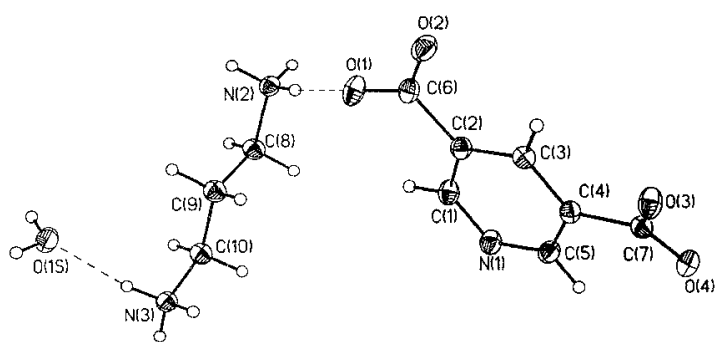

Fig. 2 Molecular structure of $\left(\mathrm{pdaH}_{2}\right)(\mathrm{py} 3,5 \mathrm{dc}) \cdot \mathrm{H}_{2} \mathrm{O}$ with hydrogen bonding.

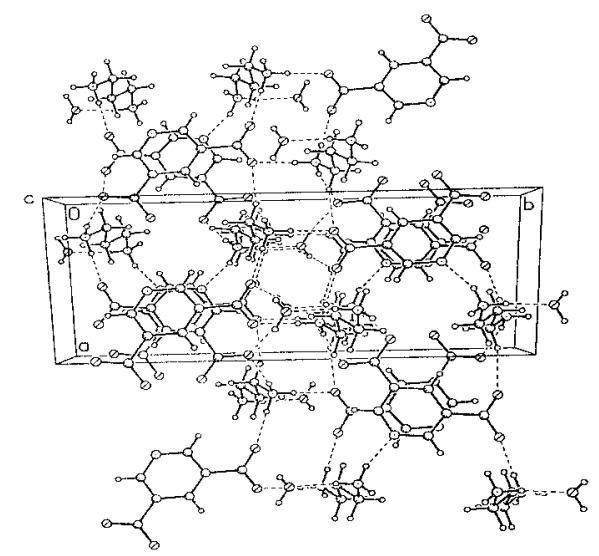

Fig. 3 Unit-cell packing diagram of $\left(\mathrm{pdaH}_{2}\right)(\mathrm{py} 3,5 \mathrm{dc}) \cdot \mathrm{H}_{2} \mathrm{O}$. Hydrogen bonds are indicated by dashed lines.

(Fig. 3). The most important features of the crystal structure of $\left(\mathrm{pdaH}_{2}\right)(\mathrm{py} 3,5 \mathrm{dc}) \cdot \mathrm{H}_{2} \mathrm{O}$ are the interactions between $\left(\mathrm{pdaH}_{2}\right)^{2+}$ and $(\mathrm{py} 3,5 \mathrm{dc})^{2-}$ fragments consisting of ion-pairing and hydrogen bonding. This compound, consequently can be considered as a supramolecular structure formed by noncovalent interactions.

\section{References}

1. H. Aghabozorg, A. Saei, and F. Ramezanipour, Acta Cryst., 2005, E61, o3242.

2. A. Moghimi, R. Alizadeh, A. Shokrollahi, H. Aghabozorg, M. Shamsipur, and A. Shokravi, Inorg. Chem., 2003, 42, 1616.

3. A. Moghimi, Sh. Sheshmani, A. Shokrollahi, H. Aghabozorg, M. Shamsipur, G. Kickelbick, M. Carla Aragoni, and V. Lippolis, Z. Anorg. Allg. Chem., 2004, 630, 617.

4. H. Aghabozorg, M. Ghadermarzi, and F. Ramezanipour, Acta Cryst., 2006, E62, o1142.

5. G. M. Sheldrick, SHELXL-97. SHELXTL V. 5.10, Structure Determination Software Suite, Bruker AXS, Madison. 